\title{
ANALISIS \& PERANCANGAN SISTEM ADMINISTRASI KEUANGAN UNTUK USAHA KECIL DAN MENENGAH KAMPUNG KUE DI SURABAYA
}

\author{
Nurul Aini ${ }^{1}$, Latifah Rifani ${ }^{2}$ \\ Fakultas Ilmu Komputer, Prodi Teknik Informatika, Universitas Narotama Surabaya \\ aininurul349@gmail.com, latifahrifani@gmail.com
}

\begin{abstract}
Abstrak
UKM adalah salah satu pelaku ekonomi dalam jumlah terbesar di Indonesia, pada tahun 2013. Hal ini diketahui dari perkiraan jumlah UKM di Indonesia sebanyak 55,2 juta yang tersebar di seluruh Indonesia (Kementrian KUKM, 3013). Akan tetapi, faktanya UKM merasa kesulitan dalam melakukan pencatatan dan menyusun laporan keuangan. Mulai dari laporan keuangan awal dari permodalan yang berasalah dari perbankan, sebagai syarat administrative sampai dengan laporan laba rugi dan neraca. Hal ini diperberat lagi dengan adanya Undang-undang perpajakan tentang pengenaan PPh final 1\% dari peredaran bruto bagi UKM. Permasalahan tersebut membutuhkan solusi nyata yang didukung oleh perkembangan teknologi saat ini secara komputerisasi (Sistem Informasi Akuntansi). Cara ini akan mengurangi tingkat kesulitan dibandingkan jika menggunakan pencatatan secara manual dan juga mengurangi adanya kesalahan data akibat human error. Sistem Informasi Akuntansi tersebut perlu diawali dengan pengembangan desain terlebih dahulu agar secara tepat dapat tepat guna sesuai dengan informasi akuntansi yang ada pada UKM. .
\end{abstract}

Kata Kunci: UKM, keuangan, desain sistem informasi,akuntansi

\section{Pendahuluan}

Pemberdayaan ekonomi kerakyatan merupakan kalimat yang sering muncul di saat kita membahas tentang Usaha Kecil Menengah (UKM) dan Koperasi. UKM merupakan pelaku ekonomi terbesar di Indonesia, pada tahun 2013 diperkirakan jumlah UKM di Indonesia sebanyak 55,2 juta yang tersebar di seluruh Indonesia (Kementrian KUKM, 3013). Di saat krisis ekonomi, sector UKM ini masih bisa tetap berdiri karena 1).sebagian besar produk UKM menghasilkan barang-barang konsumsi, khususnya yang tidak tahan lama; 2) mayoritas mereka menggunaan pembiayaan non-banking; 3). Umumnya hanya memproduksi barang tertentu saja; 4). Terbentuknya usaha-usaha kecil baru sebagai akibat banyaknya pemutusan hubungan kerja pada sector formal akibat krisis (Basri, 2003).

Masalah klasik yang sering muncul adalah masalah akses permodalan. UKM akan mengalami kesulitan untuk meminjam uang di bank, padahal untuk mengembangkan usahanya mereka membutuhkan dana yang cukup besar yang tidak mungkin jika meminjam pada non-banking.
Penyebabnya adalah mereka belum pernah melakukan pencatatan transaksi keuangan secara benar. Padahal untuk mendapatkan permodalan dari perbankan, mereka harus memenuhi syarat administratif salah satunya adalah laporan keuangan minimal laporan laba rugi dan neraca. Selain itu, adanya Undang-undang perpajakan tentang pengenaan $\mathrm{PPh}$ final $1 \%$ dari peredaran bruto bagi UKM.

Berdasarkan pada permasalahan tersebut, penggunaan komputer untuk melakukan pencatatan dan penyusunan laporan keuangan akan mengurangi tingkat kesulitan dibandingkan jika menggunakan pencatatan secara manual. Jika ditinjau dari segi biaya memang membutuhkan investasi awal untuk membeli perangkat komputer, tetapi manfaat yang dirasakan akan lebih banyak. Dengan Sistem Informasi Akuntansi diharapkan mereka dapat memproses transaksi keuangan yang pada akhirnya akan tersusun laporan keuangan dengan mudah. Dengan demikian, perumusan masalah yang kami ajukan adalah: 
1. Bagaimana desain Sistem Informasi Akuntansi penerimaan dan pengeluaran kas yang dapat diaplikasikan pada UKM?

2. Bagaimana desain Sistem Informasi Akuntansi berdasarkan komputer yang dapat diaplikasikan pada UKM?

Tujuan penelitian ini adalah mendesain Sistem Informasi Akuntansi penerimaan dan pengeluaran kas serta mendesain Sistem Informasi Akuntansi berdasarkan komputer yang dapat diaplikasikan pada UKM sehingga memudahkan UKM untuk menyusun laporan keuangan.

\section{Metodologi Penelitian}

Penelitian ini menggunakan pendekatan kualitatif, karena permasalahan yang dibahas adalah masalah yang terjadi pada satu setting tertentu yang membutuhkan penjelasan yang detil tentang penyusunan desain sistem informasi akuntansi berdasarkan komputer yang dapat diaplikasikan pada UKM.

Teknik pengumpulan data yang dilakukan dalam penelitian ini dikelompokkan menjadi dua, yaitu : data utama dan data pendukung. Untuk data utama diperoleh dari para informan yaitu orang-orang yang terlibat dalam kegiatan UKM, sedangkan data pendukung diperoleh dari dokumen-dokumen berupa catatan, gambar dan bahan-bahan lain yang dapat mendukung dalam penelitian ini. Teknik pengumpulan data dalam penelitian ini dilakukan dengan cara:

1. Observasi

Dalam kegiatan observasi ini, peneliti akan mengamati obyek penelitian yaitu UKM, untuk mencari data secara langsung di lapangan baik melalui manusia maupun non-manusia seperti dokumen atau catatan yang tersedia. Dokumendokumen atau catatan-catatan ini yang nantinya akan menjadi acuan untuk pembuatan desain Sistem Informasi Akuntansi yang sesuai dengan UKM tersebut.

2. Wawancara

Dalam penelitian ini wawancara dilakukan dengan mengajukan pertanyaan secara lisan kepada pimpinan/pemilik UKM terkait dengan permasalahan yang diangkat. Pada umumnya pada UKM, pemilik juga sekaligus sebagai pimpinan perusahaan yang mengetahui semua informasi keuangan maupun nonkeuangan pada perusahaannya.

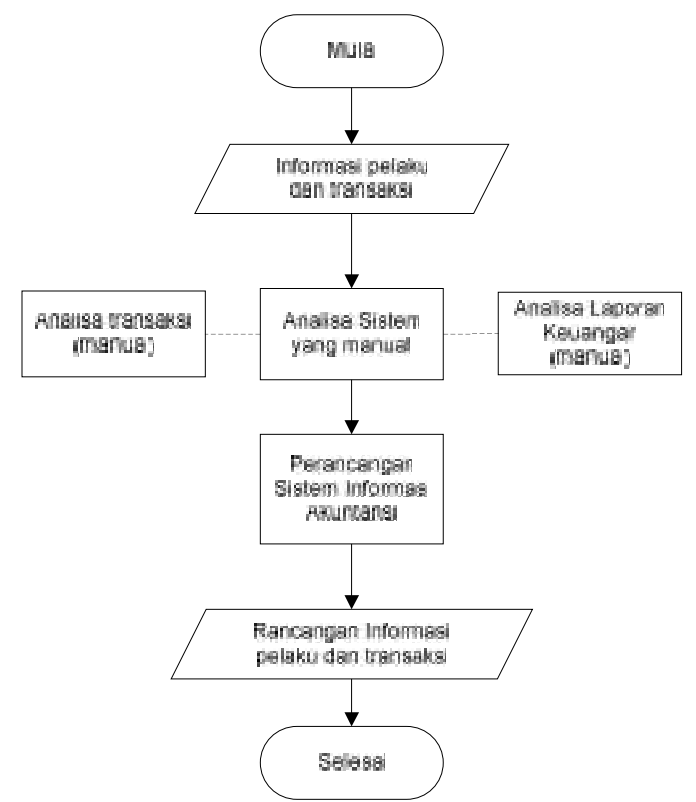

Gambar 2.1. Flowchart Metodologi Penelitian

\section{Hasil Pembahasan}

Akutansi secara manual memiliki beberapa proses yang cukup rumit dan rawan dengan human error. Alur proses pengolahan keuangan dalam suatu unit usaha diawali dengan adanya bukti transaksi jual beli, kemudian dilanjutkan dengan jurnal, perekaman pada buku besar, neraca saldo, neraca lajur, dan akhirnya laporan keuangan. Adanya kemungkinan kesalahan ini membutuhkan sistem otomatis bantuan perkembangan teknologi yang menjadi usulan penelitian ini.

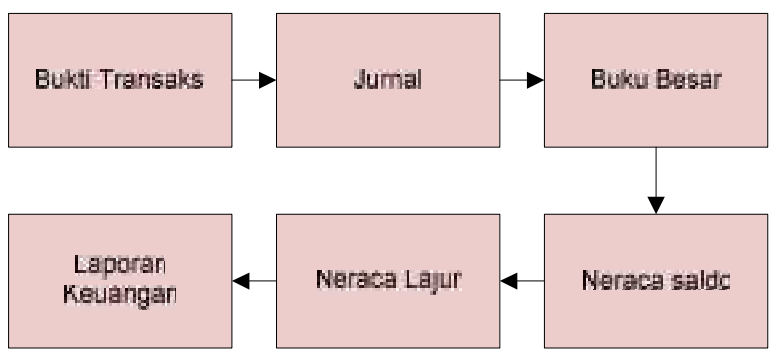

Gambar 3.1. Alur proses manual Akuntansi

Pada perancangan sistem, baru ditekankan pada input data, pengelolaan data proses akuntansi, dan pembuatan laporan. Pada proses perancangan ini digunakan beberapa flowchart diantaranya adalah flowchart dokumen dan flowchart sistem.

\subsection{Flowchart Dokumen Penerimaan Kas}

Flowchart dokumen yang dibuat merupakan alur proses bisnis dari penjualan kue dari mulai 
pengambilan pesanan sampai pembuatan laporan. Proses ini melibatkan 3 pelaku, yaitu bagian penjualan, pemilik dan bagian keuangan.

Diawali dengan proses pemesanan oleh konsumen kepada bagian penjualan. Bagian penjualan akan mencatat data pemesanan tersebut, kemudian membuat Faktur Penjualan Tunai (FPT) rangkap 3. FPT ini diserahkan kepada pemilik untuk mendapatkan pengesahan beserta pembayaran tunai dari pembeli. Kemudian FPT yang sudah disahkan tersebut diberikan masing-masing FPT 1 kepada bagian penjualan yang kemudian diberikan kepada pembeli beserta barang yang telah dibeli, FPT 2 disimpan oleh pemilik, dan FPB 3 diberikan kepada bagian keuangan. Di bagian keuangan, FPT 3 ini akan dicatat dalam jurnal penerimaan kas kemudian dibuat laporan dengan menggunakan sistem komputerisasi..

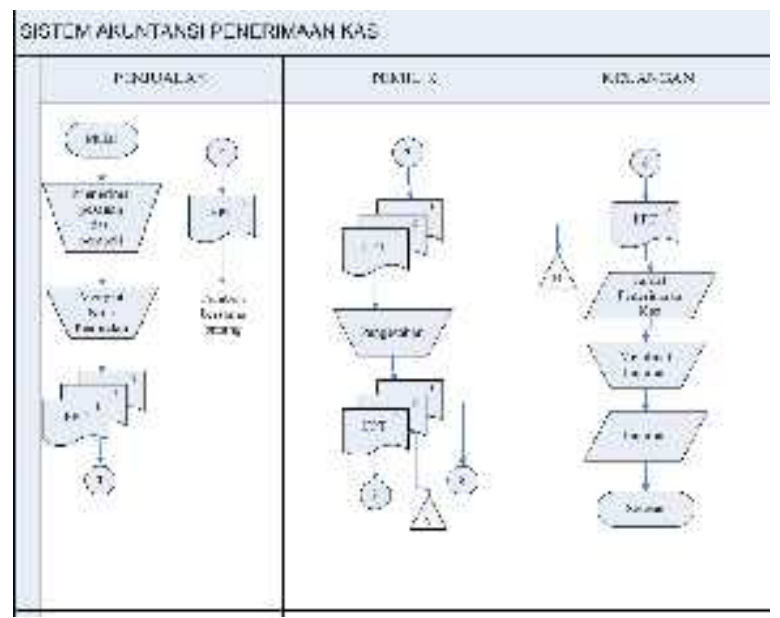

Gambar 3.2. Flowchart Dokumen Penerimaan Kas

\subsection{Flowchart Dokumen Pengeluaran Kas}

Dalam sistem pengeluaran kas fungsi yang terkait hanya ada 2 fungsi yaitu : Pemilik dan bagian keuangan. Semua kebutuhan pengeluaran kas dikendalikan oleh pemilik, tetapi harus diketahui oleh bagian keuangan. Pemilik akan membuat Permintaan Pengeluaran Kas Kecil (PPKK) rangkap 2, PPKK tersebut akan diberikan kepada bagian keuangan, bagian keuangan akan memberikan uang sesuai PPKK kepada pemilik beserta PPKK 1, PPKK 2 akan disimpan sementara oleh bagian keuangan. Pemilik mulai mengeluarkan uang dan menunjukkan bukti pendukung (BP) dan membuat Bukti Pengeluaran Kas Kecil (BPKK). PPKK 1, BP dan BPKK diserahkan ke bagian keuangan yang akan diperiksa pertanggungjawaban pemakaian dana kas kecil dan membandingkan dengan PPKK 2 jika sudah sesuai, bagian keuangan akan memberikan PPKK 1 kepada pemilik sebagai arsip, PPKK 2, BP dan BPKK akan disimpan di bagian keuangan dan dimasukkan dalam jurnal pengeluaran kas serta membuat laporan keuangan dengan menggunakan sistem komputerisasi. Berikut ini gambar flowchart dokumen sistem akuntansi pengeluaran kas..

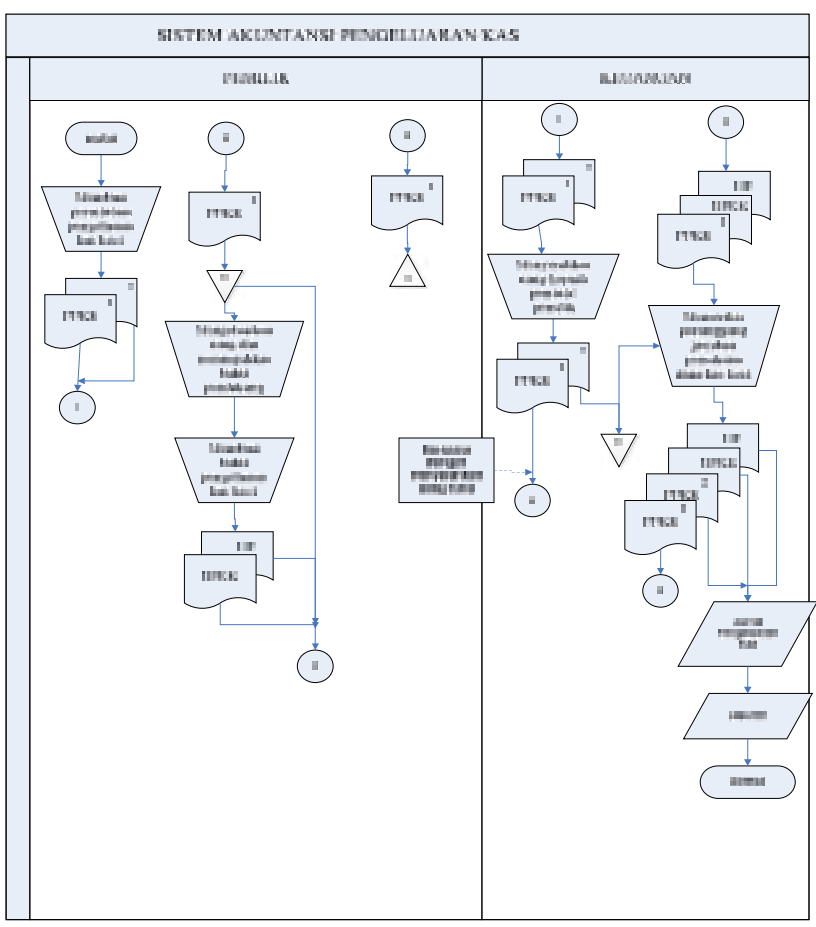

Gambar 3.3. Flowchart Dokumen Pengeluaran Kas

\subsection{Flowchart Sistem Akuntansi}

Flowchart ini menunjukkan alur dalam transaksi akuntansi pada sistem. Dimulai dengan melakukan proses login dengan memasukkan username dan password. Apabila proses login sukses, maka akan muncul tampilan form untuk memasukkan tanggal transaksi, nomor transaksi dan transaksi apa yang terjadi. Inputan tersebut akan diproses dan disimpan ke file data akuntansi.

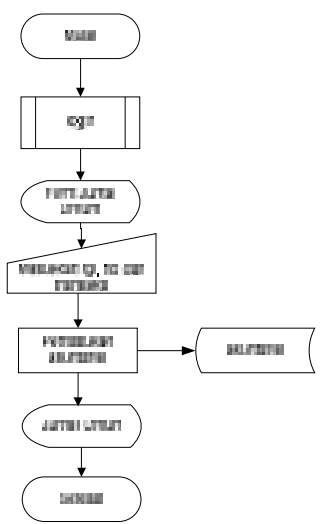

Gambar 3.4. Flowchart Sistem Akuntansi 


\subsection{Flowchart Sistem Pembuatan Laporan}

Sistem ini melakukan beberapa laporan, yaitu laporan jurnal, laporan buku besar, laporan neraca saldo, laporan neraca lajur, dan laporan keuangan. Untuk memulai proses ini, admin harus melakukan proses login terlebih dahulu. Setelah sukses, admin memasukkan periode laporan apa yang ingin dibuat. Kemudian permintaan ini akan diproses dengan melihat data mana yang akan diminta. Setelah mengambil data dari database, maka hasil laporan yang sudah diproses akan ditampilkan di layar. Kemudian admin akan ditanya apakah ingin mencetak laporan yang sudah dibuat atau tidak. Jika iya, maka laporan akan tercetak, dan jika tidak, maka sistem akan keluar dari menu laporan.

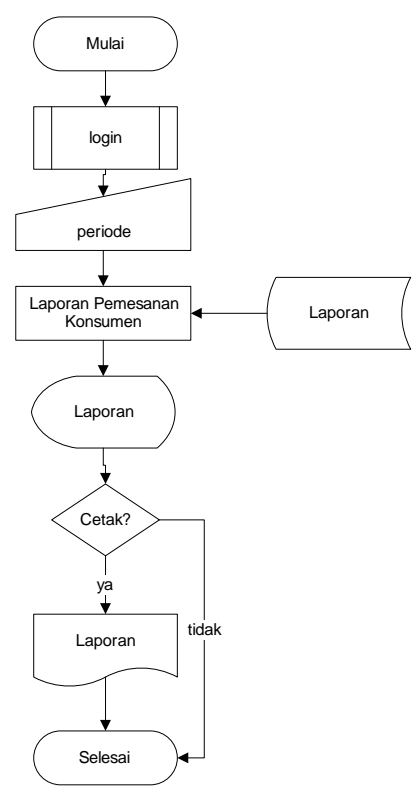

Gambar 3.5. Flowchart Sistem Pembuatan Laporan

\subsection{Database Sistem}

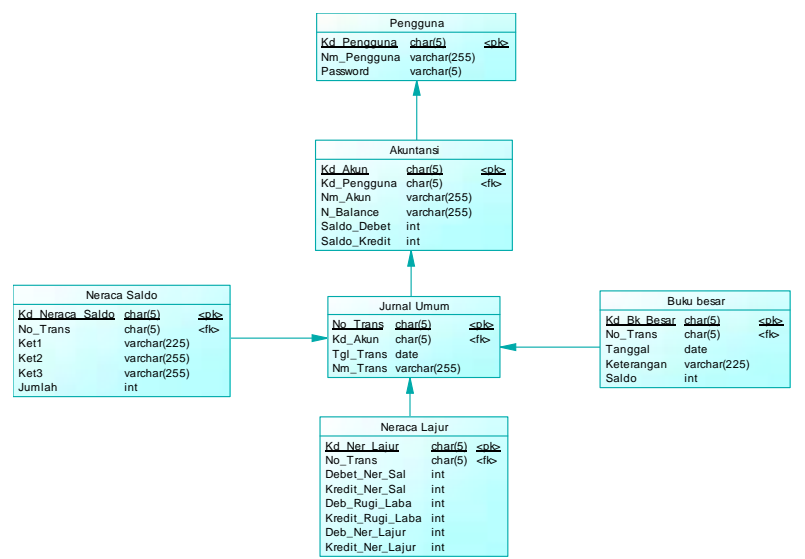

Gambar 3.6. Database Sistem
Pada database sistem, terdapat 6 entiti yang merupakan tabel berisikan atribut-atribut yang merupakan isi dari tabel tersebut. Keenam entiti tersebut yaitu tabel pengguna, tabel akuntansi, tabel jurnal umum, tabel buku besar, tabel neraca saldo, dan tabel neraca lajur. Masing-masing tabel memiliki atribut-atribut dan diperlukan dan masing-masing atribut memiliki jenis data dan jumlah karakter yang disesuaikan dengan keperluan.

\subsection{Desain Interface}

Pendesainan Sistem Informasi Akuntansi merupakan hal terakhir dan yang paling utama dalam penelitian ini. Desain interface yang didesain merupakan hasil dari penelitian yang dilakukan di lapangan, dalam hal ini, desain yang dibentuk disesuaikan dengan keperluan dari UKM Kampung Kue. Sistem didesain semudah mungkin agar admin ataupun pengguna sistem tidak merasa kesulitan dalam mengoperasikannya.

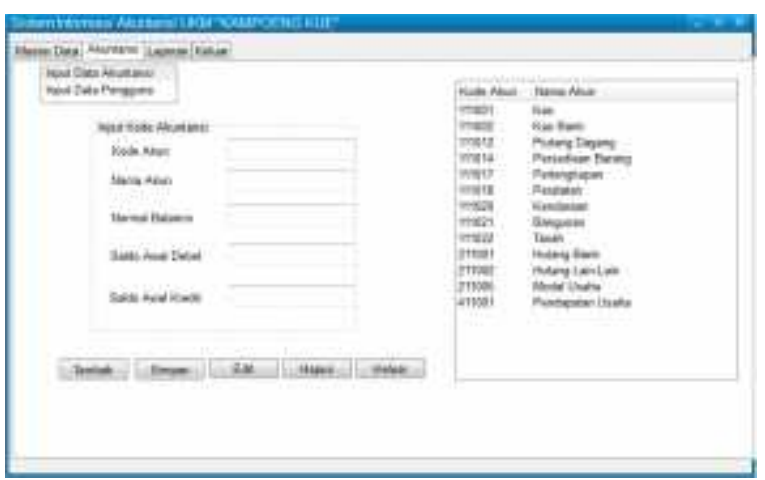

Gambar 3.7. Desain Halaman Input Data Akuntansi

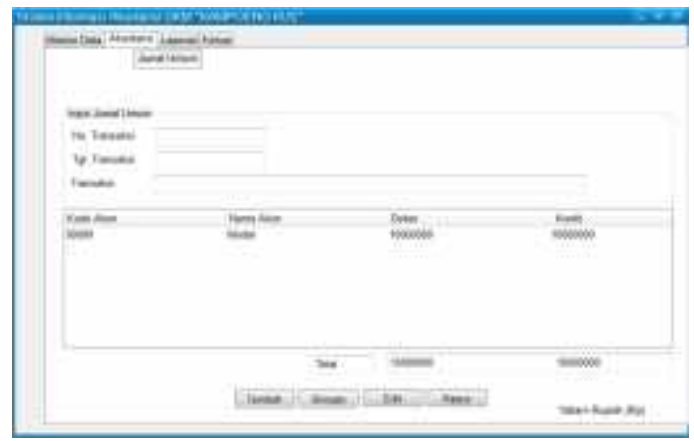

Gambar 3.8. Desain Halaman Jurnal Umum 
Nurul Aini ${ }^{1}$, Latifah Rifani ${ }^{2}$, Analisis \& Perancangan Sistem Informasi Administrasi ...

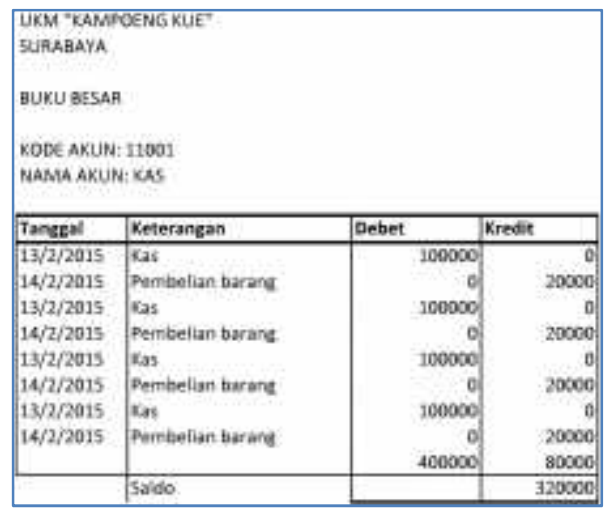

Gambar 3.9. Contoh Laporan Buku Besar
TANINDO). Fakultas Ekonomi Universitas Sebelas Maret. Surakarta

Widjajanto, Nugroho. 2001. Sistem Informasi Akuntansi. Erlangga. Jakarta

\subsection{Kesimpulan}

Berdasarkan permasalahan yang ada pada UMKM Kampung Kue, peneliti memberikan solusi untuk mengatasi kesulitan dalam menyusun laporan keuangan yaitu dengan membuat desain sistem informasi akuntansi berbasis komputerisasi. Desain yang disusun dalam penelitian ini adalah desain sistem untuk siklus penyusunan laporan keuangan yang disesuaikan dengan kondisi UMKM agar dapat membantu mempermudah dalam menyusun laporan keuangan. Aplikasi ini menunjang perancangan sistem informasi akuntansi pada UKM Kampoeng Kue Surabaya

\subsection{Saran}

Berdasarkan permasalahan yang terjadi pada UMKM kampung kue yaitu kesulitan dalam membukukan transaksi dan menyusun laporan keuangan sederhana secara manual, peneliti menyarankan secara bertahap mereka dapat menyusun laporan keuangan berbasis komputerisasi yang lebih mudah, efektif dan efisien

\section{Daftar Pustaka}

Baridwan, Zaki. 2002. Sistem Akuntansi. Penerbit BPFE. Jakarta

Basri, Faisal. 2003. Dinamika UKM di Antara Gemuruh Retorika Politik dan Mitos. Seminar Pembangunan Hukum Nasional VIII. Denpasar Bali

Bodnard, George.H., Hopwood, W.S. 2000. Sistem Informasi Akuntansi. Edisi Indonesia. Salemba Empat. Jakarta

Ferdian. 2010. Perancangan Sistem Informasi Akuntansi (Studi kasus pada CV. MITRA 